\section{Arsenic exposure assessment of children living in a lead mining area in Southeastern Brazil}

\author{
Avaliação da exposição de crianças ao arsênio \\ em área de mineração de chumbo na \\ Região Sudeste do Brasil
}

\author{
${ }^{1}$ Instituto Adolfo Lutz, São \\ Paulo, Brasil. \\ 2 Centro de Controle de \\ Intoxicações, Universidade \\ Estadual de Campinas, \\ Campinas, Brasil. \\ 3 Instituto de Geociências, \\ Universidade Estadual de \\ Campinas, Campinas, Brasil. \\ ${ }^{4}$ Centro de Ciências da \\ Saúde, Universidade \\ Estadual de Londrina, \\ Londrina, Brasil. \\ 5 Companhia de Pesquisas \\ de Recursos Minerais, Rio de \\ Janeiro, Brasil. \\ Correspondence \\ M. M. B. Paoliello \\ Departamento de Patologia \\ Análises Clínicas e \\ Toxicológicas, Centro de \\ Ciências da Saúde, \\ Universidade Estadual de \\ Londrina. \\ Av. Robert Koch 60, Londrina, \\ PR 86038-440, Brasil. \\ monibas@sercomtel.com.br
}

\begin{abstract}
Environmental contamination by arsenic compounds in the Ribeira River Valley, São Paulo, Brazil has already been observed. Lead mining and refining activities had been carried on since late colonial times and finished recently, at the end of 1995. The source of As in the region is known to be mainly from arsenopirite geological presence in the lead ore. Chronic exposure to arsenic compounds may cause peripheral vascular disorders, hyperpigmentation, hiperkeratosis and cancer of the skin, bladder, lung, liver and other internal organs. The purpose of this study was to assess children exposure to arsenic from environmental sources in the region. Urine samples from children between 7 to 14 years old were collected at the following localities: Cerro Azul (Paraná); urban areas of Ribeira (São Paulo) and Adrianópolis (Paraná); Vila Mota neighborhood (rural area of Adrianópolis) and Serra neighborhood (Iporanga, São Paulo), identified as groups 1,2, 3 and 4, respectively. Group 1 was considered as non-exposed control group. Toxicologically relevant forms of As were determined by atomic absorption spectrometry with hydride generation system. The median values of urine arsenic levels obtained in groups 1, 2, 3 and 4 were respectively: 3.60, 6.30, 6.41 e $8.94 \mu \mathrm{g} / \mathrm{L}$.
\end{abstract}

Arsenic Poisoning; Mining; Environmental Exposure
Alice Momoyo Sakuma 1

Eduardo Mello De Capitani 2

Bernardino Ribeiro Figueiredo 3

Franca Durante de Maio 1

Monica Maria Bastos Paoliello 4

Fernanda Gonçalves da Cunha 5

Maria Cristina Duran 1

\section{Introduction}

Several studies carried out in India, China, Taiwan, Chile and Argentina have shown that longterm environmental exposure to high arsenic levels, mainly through drinking water, can increase the incidence of skin, lung, liver and bladder cancer, as well as cause the occurrence of a severe debilitating arterial vascular disease (black foot disease, described in Taiwan) 1,2,3,4,5,6,7. Absorption of arsenic by humans depends on the nutritional status, concentration and duration of the exposure, as well as on the synergistic and antagonistic relationships with other substances present in water, like humic acid. Malnutrition tends to increase susceptibility to arsenic from environmental contamination 2,8 .

Toxicity of arsenic depends on its chemical form. In fish and seafood, arsenic is present basically in non-toxic organic forms, such as arsenobetaine and arsenocoline. Both are very stable forms of arsenic that are not metabolized in the organism after absorption, and are directly excreted by the kidneys. The total amount of arsenic in urine is strongly influenced by arsenic ingestion through diet 9,10 .

In humans, inorganic arsenic compounds are metabolized into trivalent and pentavalent organic arsenicals. Toxicity hierarchy of arsenic compounds decreases from arsenite $>\mathrm{MMAII}^{\mathrm{II}}$

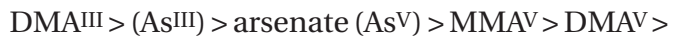
TMAO 11,12,13,14. Trimethylarsine oxide (TMAO) is 
not found in human urine 12 . Therefore, speciation studies must be done in arsenic exposure evaluation studies.

Chemical speciation aims to assess exposure to toxic, and low or non-toxic forms of arsenic. Several analytical techniques may be used for speciation studies, such as high performance liquid chromatography (HPLC) coupled with flow injection-hydride generation atomic absorption spectrometry (HG AAS) 15,16, or inductively coupled plasma mass spectrometry detection (ICP MS) 17. Guo et al. 18 have proposed methods for detecting only the toxicological relevant species using cystein and HG AAS.

Arsenic is excreted mainly through the renal system. Therefore, the urine is the best biological specimen for assessing recent exposure to this element 19,20. According to Hinwood et al. 21, there is no need for 24-hour urine sampling to assess environmental inorganic arsenic exposure. There are no significant differences between the urinary inorganic arsenic concentrations for the different sample types, whether results are adjusted by urine creatinine or not 22 . Gong et al. 23 performed studies on urine physical-chemical stability for arsenic determination and observed that samples remain stable for up to 114 days when kept at $-20^{\circ} \mathrm{C}$.

In Brazil there are few studies assessing environmental arsenic contamination in mining areas. In the State of Amapá, in the northern part of the country, aquifers in a manganese mining and milling operation in Serra do Navio are contaminated due to high arsenic levels occurring in industrial waste that is stocked nearby. Nevertheless, water samples from residential areas showed arsenic levels on average below $10 \mu \mathrm{g} / \mathrm{L} 24$. In the Ribeira de Iguape river valley, located in the southern region of the State of São Paulo and east of the State of Paraná, Brazil, Silva 25 found abnormal arsenic levels in river sediments, possibly due to illegal unloading of mining waste in the rivers and also due to natural arsenic contamination. In Nova Lima, in the Southeast Region of Brazil, the Morro Velho Mining Company has been unloading gold mining and milling waste directly into the Cardoso stream, contributing to arsenic contamination of the environment 26 .

The Ribeira de Iguape river valley has a long and rich history of mining activities that goes back to late colonial times. The environmental impact of these activities regarding metal contamination of water, soil and sediment, has been assessed in recent years mainly focused on lead and arsenic concentrations 25,27.

In the median part of the valley soils and rocks rich in arsenic can be found, principally in a geologic outcrop named Faixa Piririca, geographically located between the cities Iporanga and Eldorado, in São Paulo State. That region did not suffer a direct impact from the operation of the lead refining plant located upstream in Adrianópolis, Paraná. Nevertheless, soils with up to $2,000 \mathrm{mg} / \mathrm{kg}$ can be found in that region due to the weathering of host rocks and gold seams containing sulfides and arsenopirite 28,29.

The objective of the present study was to assess the arsenic exposure of children living in a region with anthropogenic and geogenic environmental sources of arsenic. Several social and demographic variables were evaluated.

\section{Materials and methods}

\section{Study population and sample collection}

The study population consisted of 398 participants chosen among children aged between 7 and 14, living in four municipalities: Cerro Azul (Paraná State), Adrianópolis (Paraná), Ribeira (São Paulo) and Iporanga (São Paulo). The sites were chosen due to their location, downstream of the Ribeira de Iguape river on the border of the states of Paraná and São Paulo. Cerro Azul is located at the source of the river, $50 \mathrm{~km}$ upstream from the mining and milling activities, and therefore the population living there was considered a non-exposed control population (group 1). Children from the urban areas of Adrianópolis and Ribeira made up group 2, with both municipalities located between 5 and $6 \mathrm{~km}$ from the mining and milling operations, where gold, silver, zinc and lead were refined. Group 3 was made up of children living in Vila Mota (in the rural area of Adrianópolis), around $800 \mathrm{~m}$ from the refining plant, and group 4 included children from Serra, a neighborhood of Iporanga, located close to another small refining plant shut down in 1993, and laying over a natural geologic arsenopirite outcrop.

Children were recruited in the schools of each municipality. During meetings with teachers and parents, the objectives of the research were fully explained and discussed. First void urine samples were collected from those children whose parents had formally approved their participation. A standard questionnaire was applied aiming to collect information about dietary habits, parents' occupation, length of residence in the place, hobbies, and drinking water patterns 30 . The present study was conducted in accordance with national and international guidelines for the protection of human subjects and the research protocol was approved by the Ethics Committee 
of the University of Campinas. All parents were asked to sign a written consent form.

Urine samples (first void) were collected in polyethylene flasks previously soaked in $20 \%$ nitric acid, rinsed with distilled water and dried. No conservatives were used and the samples were kept frozen at $-20^{\circ} \mathrm{C}$ until analyzed. Urine sampling was collected from June 1999 to November 2001. The arsenic species in human urine is stable for at least six months preserved at $-20^{\circ} \mathrm{C} 6$. The arsenic content was determined as soon as possible.

\section{Arsenic analysis}

Toxicologically relevant arsenic compounds were detected in urine samples using flow injectionhydride generation atomic absorption spectrophotometer (Model FIAS 400, Analyst 100; Perkin Elmer, São Paulo, Brazil). This method is based on the complexation of toxicologically relevant arsenic compounds containing cystein, followed by reduction by sodium borohydride and using hydrochloric acid as a carrier 18 .

The urine arsenic analysis was performed using Standard Reference Material (Toxic Metals in Freeze-Dried Urine NIST SRM 2670 - normal level. National Institute of Standards and Technology, USA), with recovery at $95 \%$. The quality assurance was performed by analyzing three SRM controls with every batch of 30 samples. The detection limit obtained for arsenic was $0.4 \mu \mathrm{g} / \mathrm{L}$ in 1:5 urine dilution, corresponding to $2.0 \mu \mathrm{g} / \mathrm{L}$ in original urine. All samples were analyzed in duplicate. The glassware and other laboratory materials were soaked in $20 \%$ nitric acid, and then rinsed with distilled-deionized water

\section{Statistical analysis}

A great number of samples showed arsenic measurements below the detection limit of the method $(2.0 \mu \mathrm{g} / \mathrm{L})$. For these cases, a value of one-half the detection limit was assigned. So, for calculation purposes, the value of $1.00 \mu \mathrm{g} / \mathrm{L}$ was attributed to each of these samples.

The distribution of results concerning the four groups showed a strong asymmetry to the right. As any attempt to transform data [logarithm, square root, cubic root and the inverse $(1 / \mathrm{x})]$ to normal distribution failed, median values were chosen and compared using the non-parametric test of Kruskall-Wallis. A 5\% level of significance was chosen for interpreting data.

Trying to identify and quantify the influence of certain variables to arsenic concentration in urine, a logistic regression model was applied. Urine arsenic concentration, as the outcome variable was dichotomized using a cut-off value of $3.60 \mu \mathrm{g} / \mathrm{L}$. This value is the median value obtained in the control group population (group 1). The option of choosing that value was based on the absence of any study defining a reference value for arsenic in urine in the country. The following analyses were done comparing the median value from group 1 with the results from the other groups.

Inclusion of independent variables in the logistic regression model was done through a preevaluation process of each variable, considering significant those that reached $25 \%$ probability ( $\mathrm{p}$ value 0.25 ).

Further analysis aimed the interaction between the chosen variables and the variable place of dwelling (population groups), considering significant the probability of interaction of less than $10 \%$ ( $\mathrm{p}$ value $<0.10$ ). The subsequent analysis in the adjusted model was done considering a level of significance of $5 \%$. Descriptive and univariate analyses of data were done using Epi Info 6.4 (Centers for Disease Control and Prevention, Atlanta, USA) and SPSS 10.0 (SPSS Inc., Chicago, USA).

\section{Results and discussion}

Table 1 shows the results of median values for urine arsenic concentration (toxic forms) in children according to the place of dwelling (variable group).

Comparing group 1 (non-exposed control) with the other groups, a significant difference in median urinary arsenic concentration appeared for all groups $(\mathrm{p}<0.001)$.

The median value of $3.60 \mu \mathrm{g} / \mathrm{L}$ in group 1 is rather similar to $3.65 \mu \mathrm{g} / \mathrm{L}$ found in a healthy United Kingdom population sample by White \& Sabbioni 31 , and very close to $4.1 \mu \mathrm{g} / \mathrm{L}$, found in a non-exposed child population in Germany 32 . Children living in urban areas close to mining and milling activities (stopped in 1995) (groups 2 and 3), showed very similar median values (6.3 and $6.4 \mu \mathrm{g} / \mathrm{L}$, respectively). Group 4, composed by children living in an old mining and natural arsenopirite geologic outcrop area showed median values of $8.94 \mu \mathrm{g} / \mathrm{L}$, significantly higher than that found in group 1 . When also compared to the other groups, median arsenic concentration found in group 4 is significantly higher $(\mathrm{p}<0.001)$.

Values of arsenic in urine found in this study are inferior to those found in children of the same age studied by Matschullat et al. 26 in Nova Lima and Santa Barbara, Minas Gerais State, Brazil, living in a huge gold mining area. In that study 
Table 1

Median urinary concentration of arsenic (toxic forms) among children according to the place of dwelling (variable group).

\begin{tabular}{lcccc}
\hline Groups & Median (arsenic $\mu \mathrm{g} / \mathbf{L}$ ) & $\mathbf{n}$ & Range (arsenic $\mu \mathrm{g} / \mathbf{L})$ & $\mathrm{p}$ value * \\
\hline 1 & 3.60 & 73 & $1-34$ & - \\
2 & 6.30 & 129 & $1-40$ & 0.001 \\
3 & 6.40 & 107 & $1-50$ & 0.001 \\
4 & 8.94 & 89 & $1-60$ & 0.000 \\
\hline
\end{tabular}

* Median test.

the mean arsenic level in urine was $25.7 \mu \mathrm{g} / \mathrm{L}$ (standard deviation $-\mathrm{SD}=19.2$; ranging form 2.2 to $106 \mu \mathrm{g} / \mathrm{L}$ ), with $19.2 \%$ of children with levels above $40.0 \mu \mathrm{g} / \mathrm{L}$. Possible explanations for that difference lies in the age of mining activities, the amount of processed ore, and the existence of an arsenic trioxide producing plant nearby.

These same authors found arsenic concentrations in environmental samples, such as ground water, between 0.4 and $350 \mu \mathrm{g} / \mathrm{L}$, with an average of $30.5 \mu \mathrm{g} / \mathrm{L}$, while in soil the arsenic concentrations varied from 200 to $860 \mathrm{mg} / \mathrm{kg}$, in sediment from 22 to $3,200 \mathrm{mg} / \mathrm{kg}$, and in the mining waste values between 300 and $2,100 \mathrm{mg} / \mathrm{kg}$. No correlation between arsenic urinary levels and children's food habits was found, so that the main contamination sources were attributed to the environment.

Polissar et al. 33 investigated a community around an arsenic trioxide plant in Tacoma (Washington, USA) that had been in activity up to 1986, for 65 years. Mean arsenic concentration in the soil around the plant was $215.0 \mathrm{mg} /$ $\mathrm{kg}$ ( median $=352.5 \mathrm{mg} / \mathrm{kg})$. Males presented urinary arsenic of $9.6 \mu \mathrm{g} / \mathrm{L}$, and females of $8.1 \mu \mathrm{g} / \mathrm{L}$. Children between 0 and 6 years old living half a mile from the source of the emission presented urinary arsenic levels twice the concentration of the control group $(48.0 \mu \mathrm{g} / \mathrm{L}$ versus $24.5 \mu \mathrm{g} / \mathrm{L})$, with a positive linear correlation with contaminated soil and domestic dust, probably due to the hand-mouth behavior typical of that age.

In order to evaluate the influence of the soil in the arsenic urinary levels, total arsenic analyses were done in $2 \mathrm{~cm}$ deep soil samples in the areas corresponding to groups 1, 3 and 4 . The mean arsenic concentrations found in the soil (average particle size of $63 \mu \mathrm{m}$ ) in the area belonging to group 1 (control), group 3 (close to the refining plant) and group 4 (mixed contamination: mining and natural arsenic outcropping) were respectively: $0.87,7.84$ and $76.9 \mathrm{mg} / \mathrm{kg}$.

The average arsenic concentration in the soil of the area belonging to group 4 (Serra, Iporanga) is between the interval of results got by Rosa 27 for the Iguape river current sediment, whose concentrations varied from 9.8 to $355.0 \mathrm{mg} / \mathrm{kg}$, and indicated an anomaly in the amount of natural arsenic found in the region, that can explain the higher levels of arsenic found in children's urine in that locality. The sediment analysis of the Furnas stream and the Betari river that cut through the Serra neighborhood, where the children from group 4 dwell, also presented a higher arsenic contamination 25,34,35.

Studies carried out by Díaz-Barriga et al. 36 in an area near a foundry in San Luis Potosí, Mexico, showed that the arsenic medians in the soil and dust were too high in Morales downtown, located $1.5 \mathrm{~km}$ from the foundry, with values of 502.4 and $857.0 \mu \mathrm{g} / \mathrm{g}$ respectively. Arsenic daily intake estimated for children dwelling on non-paved streets, in the least contaminated area, was of $1 \mu \mathrm{g} / \mathrm{kg} / \mathrm{day}$, and in the most contaminated one was of $19.8 \mu \mathrm{g} / \mathrm{kg} /$ day, a very high number when compared to the reference dose established by the Environmental Protection Agency 37, that is $1 \mu \mathrm{g} / \mathrm{kg} /$ day. The ingestion of soil contributed with $88 \%$ of the exposure, while in the arsenic low-exposure area soil contribution was of $30 \%$. Arsenic measurement of these children's urine showed high values. The median values found for the control group and for the exposed children were 88.1 and $196.2 \mu \mathrm{g} / \mathrm{L}$ respectively.

Playing outdoors on the ground can be a source of exposure to arsenic for children in contaminated areas. In our study median values of arsenic in urine were found to be significantly higher in children who played on the ground $(6.80 \mu \mathrm{g} / \mathrm{L})$ compared to children who did not

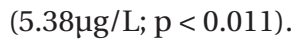

Hwang et al. 22 evaluated the impact of environmental sources in the arsenic body burden of 414 children who had lived for less than 72 months in Anaconda, Montana, where a copper foundry was in full operation. Soil, dust, water, and urine samples were taken for analysis. Mean arsenic levels in the soil varied from 121 to 
Logistic regression model results showing odds ratio (OR) for urinary arsenic levels of each group compared to group 1 (control population).

\begin{tabular}{lccccc}
\hline Studied groups & $\beta$ & Standard error & p value & OR & 95\%Cl \\
\hline Group 2 vs. group 1 & 1.086 & 0.223 & 0.000 & 3.16 & $2.11-4.73$ \\
Group 3 vs. group 1 & 1.596 & 0.283 & 0.000 & 2.96 & $1.92-4.58$ \\
Group 4 vs. group 1 & 1.151 & 0.206 & 0.000 & 4.93 & $2.83-8.59$ \\
\hline
\end{tabular}

$236 \mu \mathrm{g} / \mathrm{g}$. Particles measuring $<250 \mu \mathrm{m}$ were the ones which presented the highest risk, because they can stick to hands or toys and be inadvertently ingested by children. Drinking water represented a small contribution to those children's exposure, for the mean arsenic level found in water which was supplied to $81.3 \%$ of the houses was $1.36 \mu \mathrm{g} / \mathrm{L}$. Meanwhile the mean arsenic level found in 447 samples of dust was $73 \mathrm{mg} / \mathrm{kg}$. The geometric mean of the species toxicologically relevant in the urine [As(III) + As(V) + MMA + DMA] was $8.6 \pm 1.7 \mu \mathrm{g} / \mathrm{L}$ ], while the total arsenic mean was $19.1 \mu \mathrm{g} / \mathrm{L}$.

Other variables were assessed in our study that could influence the levels of urinary arsenic in children, such as: consumption of milk, fish, chicken, meat, vegetables and fruit produced by local farmers or at own back yards, as well as kind of water consumption. Data obtained by White \& Sabbioni 31 confirmed the necessity of displaying food habits in detail with the purpose of controlling this confounding factor in low environmental exposure studies. The nutritional status of the individuals influences directly the absorption of arsenic 8 . Aiming statistical analysis, the population was divided as follows: consuming up to once a week those items, or consuming more than once a week. In relation to other types of food, a qualitative assessment of the kind "yes" or "no" was performed. The univariate analysis of urinary arsenic in relation to food consumption for each one of the groups was done. Results showed that children from groups 2 and 3 , which consumed less meat, presented higher levels of arsenic in their urine. These levels were significantly different $(\mathrm{p}=0.000)$.

Regarding chicken consumption, it was observed that in the least contaminated area (group 1), urinary arsenic levels were generally higher in children that consumed less chicken. Both observations might indicate that a smaller consumption of proteins could provide a higher arsenic absorption, which was more evident in group 2 . On the other hand, in group 4 , from an area geologically contaminated by arsenic, it was observed that a larger consumption of chicken led to a higher concentration of urinary arsenic, contradicting the latter statement and the hypothesis of the nutritional status according to Mandal et al. 8 .

Regarding milk consumption, no significant difference was observed in the levels of urinary arsenic in children who consumed it or not.

The results indicated a low consumption of fish by the studied population, considering that $74.1 \%$ of the children did not consume it. No significant differences in arsenic levels were found among those who consumed fish or not, in all studied groups. Trepka et al. ${ }^{32}$ determined total arsenic in urine of children between 5 to 14 years, and found significant statistical differences among those who had consumed fish at least once a week, and those who had not consumed this type of food for the last 7 days. Le et al. ${ }^{9}$ noted that the consumption of seafood led to an increase of excretion of inorganic forms of arsenic and MMA and DMA, mainly marine algae that are rich in arsenosugars.

Regarding the consumption of vegetables and fruits produced in the region, no significant statistical differences were found in groups. Logistic regression analysis was also done, considering the variable urinary arsenic concentration, with the cutoff point at $3.60 \mu \mathrm{g} / \mathrm{L}$, which corresponds to the median concentration in the children from group 1 (control).

A logistic regression model was adjusted from the previous selection, taking into account all the variables: group, gender, consumption of fish, milk, meat, chicken, fruit, and vegetables, and playing on the ground, because they presented a probability value of correlation smaller than 0.25 . After this adjustment, only the variable "group" (locality of dwelling) presented significance ( $p<0,001$ ), becoming the single variable to remain in the model.

Some interactions with the variable "group" were also tested, with no significant results $(\mathrm{p}>$ 
$0.25)$. The results for the final model are presented at Table 2.

Free from influence of the other variables, it was possible to observe that children from group 2 had 3.16 times the chance of presenting arsenic concentrations superior to $3.60 \mu \mathrm{g} / \mathrm{L}$, compared to children belonging to group 1 (95\%CI: 2.1-4.73). For group 3, compared to group 1, the odds ratio (OR) is 2.96 (95\%CI: 1.92-4.58), and for group 4 compared to group 1 the OR is 4.93 (95\%CI: 2.83-8.59).

\section{Conclusions}

Children from the studied population showed different levels of exposure to arsenic, considering the dwelling place as the only variable that presented significance. The group 4 , living in
Serra neighborhood (Iporanga) was the one that presented the highest level of urinary arsenic, being followed by groups 2 and 3 from Adrianópolis/Ribeira and Vila Mota, respectively.

The natural presence of arsenic in Iporanga, allied to the anthropic contamination resultant from mining activity may explain the higher urinary arsenic values among those children. The median arsenic values of the four studied population groups do not warrant immediate health concern. However, regular urinary arsenic monitoring must be established in the region, for two important arsenic sources continue to exist in the environment: residual anthropogenic arsenic from mining activities, and geologic arsenic from arsenopirite outcrops, naturally contaminating the soil. Deforestation and soil erosion must also be constantly monitored. No exposure to arsenic was confirmed through consumption of food.

\section{Resumo}

Contaminação ambiental por compostos de arsênio no Vale do Ribeira, São Paulo, Brasil, tem sido já observada. As atividades de mineração e refinamento do chumbo têm ocorrido desde a época colonial e foram encerradas recentemente, no final de 1995. A principal fonte de arsênio na região é arsenopirita que ocorre geologicamente no minério de chumbo. Exposição crônica aos compostos de arsênio podem causar desordens vasculares periféricas, hiperpigmentação, hiperqueratose, além de câncer de pele, bexiga, pulmão, fígado e outros órgãos. O objetivo do presente estudo foi avaliar a exposição de crianças ao arsênio proveniente de fontes ambientais na região. Amostras de urina de crianças entre 7 e 14 anos foram coletadas das seguintes localidades: Município de Cerro Azul (Paraná), região urbana dos municípios de Ribeira (São Paulo) e Adrianópolis (Paraná); bairro Vila Mota (área rural de Adrianópolis) e bairro Serra (Ipiranga, São Paulo), identificados como grupos 1, 2, 3 e 4, respectivamente. O grupo 1 foi considerado não exposto (grupo controle). As formas de arsênio toxicologicamente relevantes foram determinadas por espectrometria de absorção atômica com sistema de geração de hidretos. Os valores medianos de arsênio obtidos nos grupos 1, 2, 3 e 4

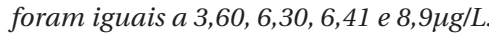

Intoxicação por Arsênico; Mineração; Exposição Ambiental 


\section{Contributors}

A. M. Sakuma participated in the conception and design of the study, collection of data and biological samples; laboratory analysis; analysis and interpretation of results, discussion, and elaboration of the manuscript. E. M. De Capitani contributed in the conception and design of the study, collection of data and biological samples; analysis and interpretation of results, discussion, and elaboration of the manuscript; and was responsible for the medical assistance of the population during the study. B. R. Figueiredo and F. G. Cunha collaborated in the conception and design of the study, collection of geologic data, discussion, and elaboration of the manuscript. F. D. Maio and M. C. Duran collaborated in the laboratory analysis; analysis, interpretation and discussion of results, and final revision of the text. M. M B. Paoliello contributed in the conception and design of the study, collection of data and biological samples; analysis and interpretation of results, discussion, and elaboration of the manuscript.

\section{References}

1. Navarro M, Sánchez M, López H, López MC. Arsenic contamination levels in waters, soils and sludges in Southeast Spain. Bull Environ Contam Toxicol 1993; 50:356-62.

2. Das D, Chatterjee A, Mandal BK, Samanta G, Chakraborti D, Chanda B. Arsenic in ground water in six districts of West Bengal, India: the biggest arsenic calamity in the world. Part 2 . Arsenic concentration in drinking water, hair, nails, urine, skin-scale and liver tissue (biopsy) of the affected people. Analyst 1995; 120:917-24.

3. Hopenhayn-Rich C, Biggs ML, Smith AH, Kalman DA, Moore LE. Methylation study of a population environmentally exposed to arsenic in drinking water. Environ Health Perspect 1996; 104:620-8.

4. Chowdhury UK, Biswas BK, Chowdhury TR, Samanta G, Mandal BK, Basu GC, et al. Groundwater arsenic contamination in Bangladesh and West Bengal, India. Environ Health Perspect 2000; 108:393-7.

5. Meza MM, Kopplin MJ, Burgess JL, Gandolfi AJ. Arsenic drinking water exposure and urinary excretion among adults in the Yaqui Valley, Sonora, Mexico. Environ Res 2004; 96:119-26.
6. Tseng CH, Huang YK, Huang YL, Chung CJ, Yang $\mathrm{MH}$, Chen CJ, et al. Arsenic exposure, urinary arsenic speciation and peripheral vascular disease in blackfoot disease-hiperendemic villages in Taiwan. Toxicol Appl Pharmacol 2005; 206:299-308.

7. Caceres DD, Pino P, Montesinos N, Atalah E, Amigo $\mathrm{H}$, Loomis D. Exposure to inorganic arsenic in drinking water and total urinary arsenic concentration in a Chilean population. Environ Res 2005; 98:151-9.

8. Mandal BK, Chowdhury TR, Samanta G, Mukherjee DP, Chanda CR, Saha KC, et al. Impact of safe water for drinking and cooking on five on five arsenic-affected families for 2 years in West Bengal, India. Sci Total Environ 1998; 218:185-201.

9. Le XC, Cullen WR, Reimer KJ. Determination of urinary arsenic and impact of dietary arsenic intake. Talanta 1993; 40:185-93.

10. Le XC, Cullen WR, Reimer KJ. Human urinary arsenic excretion after one-time ingestion of seaweed, crab, and shrimp. Clin Chem 1994; 40:617-24. 
11. Christian WJ, Hopenhayn C, Centeno JA, Todorov T. Distribution of urinary selenium and arsenic among pregnant women exposed to arsenic in drinking water. Environ Res 2006; 100:115-22.

12. Hirano S, Kobayashi Y, Cui X, Kanno S, Hayakawwa T, Shraim A. The accumulation and toxicity of methylated arsenicals in endothelial cells: important roles of thiol compounds. Toxicol Appl Pharmacol 2004; 198:458-67.

13. Aposhian HV, Zakharyan RA, Avran MD, SampayoReyes A, Wollenberg ML. A review of the enzimology of arsenic metabolism and a new potencial role of hidrogen peroxide in the detoxication of the trivalent arsenic species. Toxicol Appl Pharmacol 2004; 198:327-35.

14. Mandal BK, Ogra Y, Suzuki KT. Identification of dimethylarsinous and monomethylarsenous acids in human urine of the arsenic-affected areas in West Bengal, India. Chem Res Toxicol 2001; 14:371-8.

15. Sur R, Dunemann L. Method for the determination of five toxicologically relevant arsenic species in human urine by liquid chromatography-hydride generation atomic absorption spectrometry. J Chromatogr B Analyt Technol Biomed Life Sci 2004; 807:169-76.

16. Akter KF, Chen Z, Smith L, Davey D, Naidu R. Speciation of arsenic in ground water samples: a comparative study of CE-UV, HG AAS and LC-ICP MS. Talanta 2004; 68:406-15.

17. Hsueh YM, Hsu MK, Chiou HY, Yang MH, Huang CC, Chen CJ. Urinary arsenic speciation in subjects with or without restriction from seafood dietary intake. Toxicol Lett 2002; 133:83-91.

18. Guo T, Baaser J, Tsalev DL. Fast automated determination of toxicologically relevant arsenic in urine by flow injection-hydride generation atomic absorption spectrometry. Anal Chim Acta 1997; 349:313-8.

19. Ma M, Le XC. Effect of arsenosugar ingestion on urinary arsenic speciation. Clin Chem 1998; 44:539-50.

20. Farmer JG, Johnson LR. Assessment of occupational exposure to inorganic arsenic based on urinary concentrations and speciation of arsenic. $\mathrm{Br} \mathrm{J}$ Ind Med 1990; 47:342-8.

21. Hinwoodd AL, Sim MS, Klerk N, Drummer O, Gerostamoulos J, Bastone EB. Are 24-hour urine samples and creatinine adjustment required for analysis of inorganic arsenic in urine in population studies? Environ Res 2002; 88:219-24.

22. Hwang YH, Bornschein RL, Grote J, Menrath W, Roda S. Urinary arsenic excretion as a biomarker of arsenic exposure in children. Arch Environ Health 1997; 52:139-47.

23. Gong Z, Lu X, Cullen WR, Le XC. Unstable trivalent arsenic metabolites, monomethylarsonous acid and dimethylarsinous acid. J Anal At Spectrom 2001; 16:1409-13.

24. Santos ECO, Jesus IM, Brabo ES, Fayal KF, Sá Filho GC, Lima MO, et al. Exposição ao mercúrio e ao arsênio em Estados da Amazônia: síntese dos estudos do Instituto Evandro Chagas/FUNASA. Rev Bras Epidemiol 2003; 6:171-85.
25. Silva RHP. Geoquímica e impacto ambiental do arsênio no Vale do Ribeira (SP-PR) [Dissertação de Mestrado]. Campinas: Instituto de Geociências, Universidade Estadual de Campinas; 1997.

26. Matschullat J, Borba RP, Deschamps E, Figueiredo BR, Gabrio TE, Schwenk M. Human and environmental contamination in the iron quadrangle, Brazil. Applied Geochem 2000; 15:181-90.

27. Rosa RT. Arsênio e metais associados na região aurífera do Piririca, Vale do Ribeira, São Paulo, Brasil [Dissertação de Mestrado]. Campinas: Instituto de Geociências, Universidade Estadual de Campinas; 1999.

28. Toujague R. Arsênio e metais associados na região aurífera do Piririca, Vale do Ribeira, São Paulo, Brasil [Dissertação de Mestrado]. Campinas: Instituto de Geociências, Universidade Estadual de Campinas; 1999.

29. Braga PS, Figueiredo BR. Comportamento de metais pesados em solos na região do Vale do Ribeira (SP). In: Anais do 41o Congresso Brasileiro de Geologia. João Pessoa: Sociedade Brasileira de Geologia; 2002. p. 231.

30. Cornelis R, Heinzow B, Herber RFM, Christensen JM, Poulsen OM, Sabbioni E, et al. Sample collection guidelines for trace elements in blood and urine. J Trace Elements Med Biol 1996; 10:103-27.

31. White MA, Sabbioni E. Trace element reference values in tissues from inhabitants of the European Union. X. A study of 13 elements in blood and urine of a United Kingdom population. Sci Total Environ 1998; 216:253-70.

32. Trepka MJ, Heinrich J, Schulz C, Krause C, Popescu $\mathrm{M}$, Wjst M, et al. Arsenic burden among children in industrial areas of eastern Germany. Sci Total Environ 1996; 180:95-105.

33. Polissar L, Lowry-Coble K, Kalman DA, Hugues JP, Van Belle G, Covert DS, et al. Pathways of human exposure to arsenic in a community surrounding a copper smelter. Environ Res 1990; 53:29-47.

34. Carvalho PSM. Avaliação da qualidade do rio Ribeira de Iguape: relatório preliminar. São Paulo: Companhia Ambiental do Estado de São Paulo; 1996.

35. Eysink GGJ. Qualidade ambiental do rio Ribeira de Iguape com relação à presença de metais pesados e arsênio. São Paulo: Companhia Ambiental do Estado de São Paulo; 2000.

36. Díaz-Barriga F, Santos MA, Mejía J, Batres L, Yáñes L, Carrizales L, et al. Arsenic and cadmium exposure in children living near a smelter complex in San Luis Potosí, Mexico. Environ Res 1993; 62:242-50.

37. Environmental Protection Agency. The U.S. Environmental Protection Agency's 1988 risk assessment for arsenic. http://www.nap.edu/openbook. php?record_id $=6444 \&$ page $=16$ (accessed on 07/ May/2007).

Submitted on 23/Jul/2008

Final version resubmitted on 29/Sep/2009

Approved on 01/Oct/2009 